\title{
Let Us Possess One World: McCahon, Abstraction and Transversal Art History
}

\author{
LUKE SMYTHE
}

\begin{abstract}
Since McCahon's death in 1987, the art world has become more diverse, and so too has his circle of admirers. One reason for his work's appeal to a diverse audience, I argue, is his impure approach to abstraction. This at once makes his paintings more accessible than they would be were they purely abstract, and allows viewers to find their own meanings in his art. To show how this is so, I consider the responses to McCahon's work of five New Zealand abstract painters: Gretchen Albrecht, Stephen Bambury, Brent Harris, Ralph Hotere and Imogen Taylor.
\end{abstract}

If one word could encompass the changes that have occurred in the New Zealand art world since McCahon stopped painting in the early 1980s, "differentiation" would be a strong contender. In the intervening decades, the cultural authority of traditional art mediums, like painting and sculpture, has declined, and a host of alternative practices have become more viable. The institutional dominance of white male artists, dealers, writers, curators and administrators has likewise diminished, in some of these professions sharply. The result is a more diverse creative landscape and a network of supporting institutions that while not yet as inclusive as they could be, have certainly improved in this regard.

In the wake of these developments, aspects of McCahon's life, his work and his legacy have come to seem outdated or problematic by current lights. Already in the 1970s, his engagements with te reo and te ao Māori had been criticised for their lack of cultural awareness, misgivings that have continued to reverberate. ${ }^{1}$ Since his death, the sacrifices made by his wife Anne for the sake of his career have been acknowledged, and she has received belated recognition for her own art. $^{2}$ The effects of McCahon's drinking and violence toward his family have likewise been acknowledged, and while the nature and extent of this impact remain difficult to gauge, it was undoubtedly adverse and has come to shade his legacy as a husband and a father. ${ }^{3}$ His artistic legacy, meanwhile, continues to cast shadows of its own, which some have deemed too lengthy: so great is his reputation in New Zealand and so extensive the attention given to his work that his stature has come to feel outsized to some observers. ${ }^{4}$ One commentator has recently suggested that his prominence reflects a legacy of bias in favour of white male artists. ${ }^{5}$

Outsized his reputation may well be, and he may indeed have accrued advantages he would not accrue today; but in spite of these misgivings and qualms about his personal life, there has been little direct criticism of his art, nor has his canonical status ever seriously been questioned. To the contrary, his standing as a, if not the, leading New Zealand modernist remains as secure as ever, and his work can claim to have achieved a semblance of the universal reach and recognition he desired for it. Academic and long-form writing on his work remains dominated by Pākehā male commentators, as it has been from the start, but authorship of the dozens of appreciative essays published on the "McCahon 100" website in the past year is a good deal more socially representative. ${ }^{6}$ So too are the backgrounds of the artists, curators and authors who have addressed his work in other quarters since his death in 1987. Evidently people from many walks of life can relate to and draw something from McCahon's work, even if this isn't what he hoped they might derive from it. 
Exactly what this was remains elusive, but it lay in the direction of leading viewers (and ideally the nation as a whole) toward a "promised" or "pure" land of spiritual and social redemption." McCahon fell short of this utopian objective, but has succeeded by other measures. Not only is his work widely admired, but the nature of this admiration suggests it has accomplished something significant in today's more differentiated art world: the ability to resonate across the social fault lines of gender, ethnicity and sexuality that are the focus of much attention and anxiety in contemporary life. Accustomed as we now are to be mindful of our situated standpoints and the limits these impose on our experience, it is unusual to encounter voices like McCahon's that address their work to dimensions of experience they insist are universal. ${ }^{8}$ This was McCahon's approach from the beginning and it lead him to look beyond division and particularity within and among social groups, in an effort to connect his work as firmly and compellingly as possible to "the human situation" at large. ${ }^{9}$ In the hands of a lesser artist, this effort at transcendence may have failed, as it did to some extent in his engagements with Māori culture and experience: but to the extent that his work appeals broadly today, his universalising aspirations have been fulfilled.

Clearly there is something in McCahon's art that facilitates its widespread appeal. But what exactly is this and where can it be found? In what follows, I consider responses to his work by New Zealand abstract artists, which suggest its success is rooted in his impure approach to abstraction. In the early 1960s, McCahon retreated from the threshold of nonobjective painting to make works that were largely nonobjective but also featured written signs and symbols and intimations of the landscape. These representational devices made his work more accessible: in their absence, his loose arrangements of dark and light geometry would have remained too enigmatic to signify effectively, as he discovered when his purely abstract paintings of the late 1950 s and early 1960 s were poorly received. ${ }^{10}$ Abstraction remained integral to his work, however, as a means of broadening its semantic reach. 


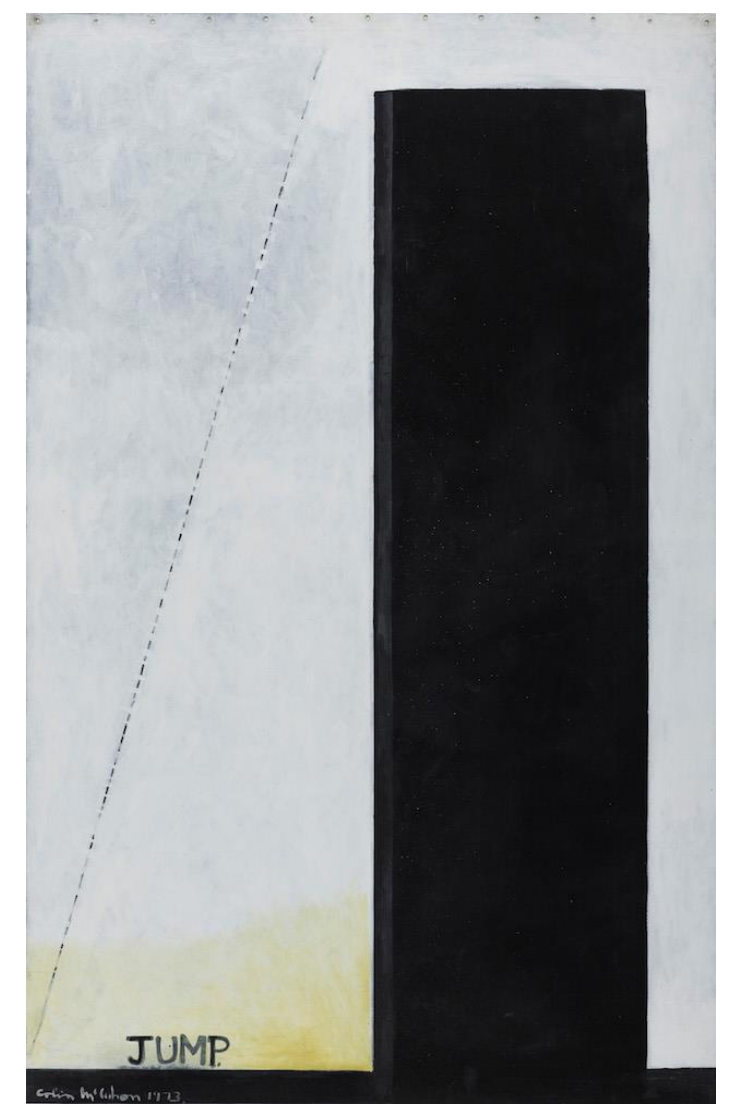

Figure 1. Colin McCahon, The Large Jump, 1973. Synthetic polymer paint on unstretched canvas, $2760 \times 1810 \mathrm{~mm}$. Auckland Art Gallery Toi o Tāmaki, bequest of Colin McCahon, 1988 (courtesy of the Colin McCahon Research and Publication Trust).

The dominant subject of McCahon's painting was a yearning for release from sin and suffering through redemptive communion with a higher power. He expressed the vicissitudes of this impulse in his own life using common Christian symbols, textual inscriptions and references to sites in the New Zealand landscape that held particular meaning for him. He hoped these illustrative elements would offer others access to his work, but in the end they were merely his way of representing phenomena he felt anybody could relate to, regardless of their spiritual beliefs or their degree of familiarity with the locations he referred to. The Jump (1973-74) [fig. 1] series, for instance, stemmed from his observations of gannets plunging from the rock pillar at Muriwai Beach. The finished paintings are doubly distanced from this scenario, however: compositionally, they reduce the landscape to an abstract diagram in which the pillar is a monolith and the birds' flight paths have become a dotted line; thematically, they recast the birds' takeoff as a leap into uncertainty. For McCahon, this leap was spiritual and its outcome, though hopefully redemptive, was unforeseeable. These terms were personal, however, and the works are also open to existential and psychological readings, as well as readings in which the outcome of the leap is less uncertain. A work like Numerals (1965) employs the generalising power of abstract metaphor in a similar fashion. It lines up numbers in an indefinite environment, marked only by a play of light and dark, and the unpredictable rise and fall of curves and inclines. The numbers progress in sequence, unsteadily but persistently, before concluding (or trailing off?) with an X that marks the spot at number ten. Here too, we are invited to see a journey of sorts that McCahon would likely have related to the Stations of the Cross. ${ }^{11}$ It isn't simply Christ's journey to Golgotha we are prompted to reflect on, however; 
nor is it McCahon's. It is equally our own, as we approach a destination that we hope but cannot know we will arrive at.

By stripping form down to its most essential elements in these and other works, McCahon sought to distil the common core of the experiences his paintings addressed. Of necessity, viewers would approach these from a range of perspectives; but where these perspectives overlapped, each experience would be shared. Were viewers to understand and accept this they might also come to recognise that the differences dividing individuals are finally inessential: more important are the deeper affinities.

As this use of abstraction makes apparent, McCahon did not deny social difference. To the contrary, he strove to accommodate it. At the same time, however, he used the general and essential connotations of abstract form to downplay the significance of difference in comparison to identity. He thus made space within his work for both conditions but felt the latter was more important. Since the late 1960s, artists as diverse in their interests and backgrounds as Ralph Hotere, Gretchen Albrecht, Stephen Bambury, Brent Harris and Imogen Taylor have approached abstraction with similar aims in mind, in each case using techniques and devices McCahon himself employed. ${ }^{12}$ The works of all five painters contain sufficient overtures toward representation to give a clearer indication of what they wish to communicate than a wholly nonobjective approach would enable. Their work is otherwise abstract, however, and as is the case with McCahon's art, this abstraction allows others to approach their images from a range of perspectives. These may differ from the artists' to varying extents, but should ideally overlap with them to some extent, a process abstraction facilitates. As in McCahon's later work, their aspiration is to use abstract imagery to build bridges from individual standpoints to the shared perspective of a larger audience. This may not be the universal audience to which McCahon's painting was addressed, and the artists in question haven't always aimed to foster social progress as McCahon did. All have, however, utilised abstraction in the same way he did: as a vehicle for overcoming, but not denying, difference. Surveying the McCahon-related works of these five artists provides the opportunity not only to account for the enduring popularity of McCahon's work, especially his output from the 1950s onward, but also to trace a transversal lineage in New Zealand painting, whose demographic inclusiveness is, I argue, useful to current efforts to diversify art history.

In a sense, McCahon's painting was impurely abstract from the outset and he merely recast and refined his approach to this way of working as time progressed. He had begun his career in the 1930s with landscapes he had reduced to their topographic essentials. His figure paintings of the 1940s had been equally rudimentary. After removing the figure from his work in the early fifties and changing course stylistically, he spent the rest of the decade producing geometricized bush and seascapes that grew increasingly abstract. In tandem with these works he made the first of his written paintings, whose backgrounds were entirely nonobjective. When compositions like Painting (1958) [fig. 2] appeared in the late 1950s and were followed by the Gates (1961-62) and a range of other wholly abstract works a few years later, it appeared that he was on track to become a nonobjective painter who would follow in the footsteps of noted modernists he admired, like Piet Mondrian, Barnett Newman and Hans Richter. ${ }^{13}$ 


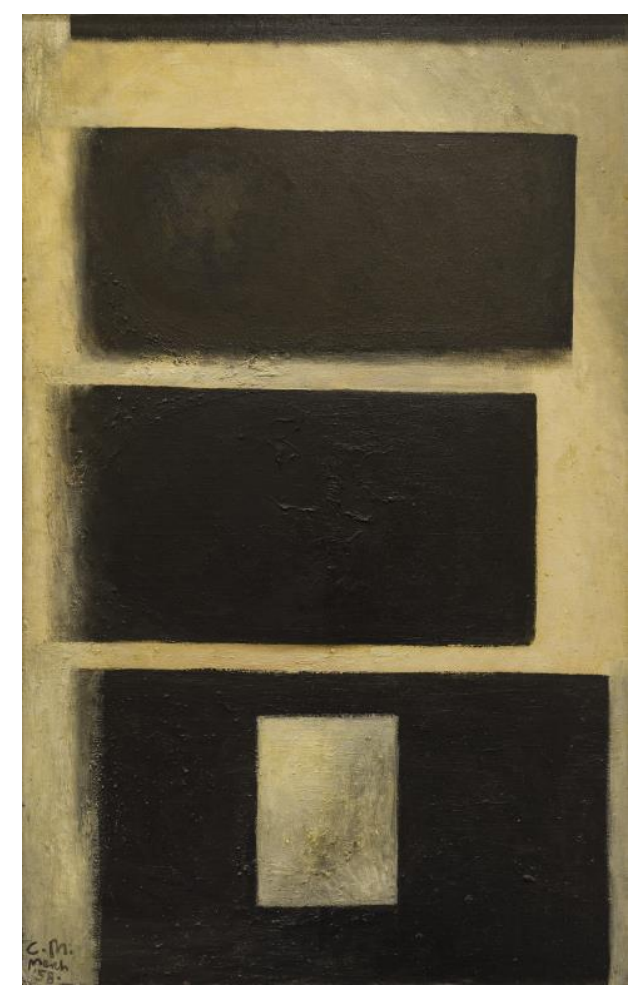

Figure 2. Colin McCahon, Painting, 1958. Oil on canvas on board, $1218 \times 764 \mathrm{~mm}$. The Fletcher Trust Collection (courtesy of the Colin McCahon Research and Publication Trust).

In the hands of these and other abstract artists in whose work McCahon is known to have had an interest, abstraction was an art of purity and universality, which aimed to purge form as extensively as possible of any trace of resemblance to the real world. Two convictions accompanied this drive to purity: first, that reducing form to its fundaments would facilitate a generalisation of art's meanings, thereby making it, in Richter's words, a "universal language"; and, second, that nonobjective form could foster an experience of transcendence toward a higher or hidden plane of experience - a Platonic world of essences and archetypes located beneath or beyond the veil of appearances, which abstraction stripped away. ${ }^{14}$ Both impulses appealed to McCahon, for whom the passage to nonobjectivity likely suggested a new and more direct way to communicate his spiritual concerns. Having failed to find an audience with his figurative works, his written paintings and his landscapes of the fifties, he seems briefly to have entertained the notion that pure abstraction could alleviate this problem. As Peter Simpson has recounted, however, Painting's receipt of the Hay's Art Prize in 1960 prompted a savagely critical response from the media. ${ }^{15}$ Reactions to the Gates were less vociferous but they were coolly received in comparison to his more legible and lyrical work of the previous decade. ${ }^{16}$ This new failure to reach an audience may have prompted McCahon to revive the modes of painting he had developed in the fifties: abstracted landscape, written compositions, and images located in the overlap between them. His approach to each would now be sparer and more forceful, however, and would remain close to the threshold of abstraction for the rest of his career-so much so that the majority of his work from the early sixties onward could be regarded as impurely abstract. This embrace of impurity was unusual for the period and would remain unorthodox until the 1980s; but such was McCahon's stature in New Zealand that by the early 1970 s, younger artists had begun painting abstractly on terms similar to his own. ${ }^{17}$ 
The first to do so was Ralph Hotere, who for some years had been making abstract paintings of uncompromising purity. Among these were his near monochrome Zero (1966-67) paintings, which he described in an artist's statement as "object[s] of visual meditation, the essence of meditation being a personal discovery in a seeming void." 18 "Seeming" was the operative word in this assertion, for the visual vacancy of the Zero works and the Black Paintings that followed them were, for Hotere, merely "a starting point, which upon contemplation may become a nucleus revealing scores of new possibilities." ${ }^{19}$ Each subsequent group of paintings he produced could be seen as an unfolding of these possibilities, especially in relation to the associative possibilities of black, which he multiplied and moulded, like McCahon, using text, religious symbols and descriptive titles, along with his own repertoire of dappled and stippled fields of dilute pigment, more forceful passages of expressive brushwork and razor-thin striations of colour.

The many overtones with which Hotere imbued black have been extensively discussed. ${ }^{20}$ They ranged in feeling from melancholy introspection and mordant humour to defiant anger and meditative openness. Perceptually, his blacks appealed as freely to the senses. From one series to the next, he used the textural and material qualities of his supports and his pigments in tandem with his texts to summon visual, auditory, tactile and olfactory associations. The quality that black thereby acquired as a generative force or ground of meaning in his work is another familiar talking point from the literature. In this connection, apt comparisons have been made to the Māori concept of Te Kore, the primal void that is the ground of all creation, and to the Catholic void preceding God's creation. ${ }^{21}$ In his work of the 1970s, in particular, Hotere followed McCahon in using white text on an unillumined ground (and sometimes the reverse) to help generate and shape these associations. He also shared McCahon's interests in religion, as in Le Pape est Mort [The Pope is Dead] (1978); in the celebration of nature, as in Godwit/Kuaka (1977) with its many "stations" of imagery to walk by; and in conservation, as expressed in the Aramoana works, which arrived in the early 1980s. His expression of these themes was personal, and so too was his adoption of McCahon's formal devices. But just as McCahon had hoped for in reaching for the universal in his art, there was an area of overlap between his own concerns and Hotere's at the impersonal level of shared experience. The extensiveness of this overlap made Hotere an ideal viewer of McCahon's work.

Hotere's address to his own work's spectators ran parallel to McCahon's in the further sense that the representational elements of his art at once offered guidance as to how his abstract imagery should be read, and granted space for others to invest it with their own meanings. After releasing his statement on the Zero paintings, Hotere famously said little about his art, leaving his works and the language they contained to speak on their own behalf. Vincent O'Sullivan and others have observed that the nature of this speech varied considerably. ${ }^{22}$ Bill Manhire's poems, for example, which Hotere often worked with, offer ample leeway for interpretation. ${ }^{23}$ Hotere's own inscriptions, like "Le Pape est Mort" (in response to the deaths of Popes Paul VI and John Paul I) and "This is a Black Union Jack" (protesting the 1981 Springbok Tour), are, by contrast, more direct and unequivocal. Yet in even the most explicit of his paintings, which would seem to offer viewers little scope to read a work on their own terms, beyond affirming or rejecting Hotere's stance on a public event, the capacity of abstraction to bridge differences is brought into play. We may not be Catholic or share Hotere's politics, but this need not prevent us from responding to the grief and the anger with which he imbued the blacks in his paintings by means of his textual and symbolic inscriptions. In the case of his political works, it seems unlikely he would have welcomed this purely affective response; but by embracing the openness of meaning that abstract imagery possesses, he unavoidably exposed his art to 
readings of this kind, which move beyond the explicit and differentiated realm of representation to the implicit and more unified plane of abstract affinity. Indeed, the net effect of his life's work is to demonstrate the power of black as a universal bed of meaning in which all states of feeling may be reconciled, their differences transcended in a higher state of unity. This then was Hotere's universalism and like McCahon he used impure abstraction to attain it.

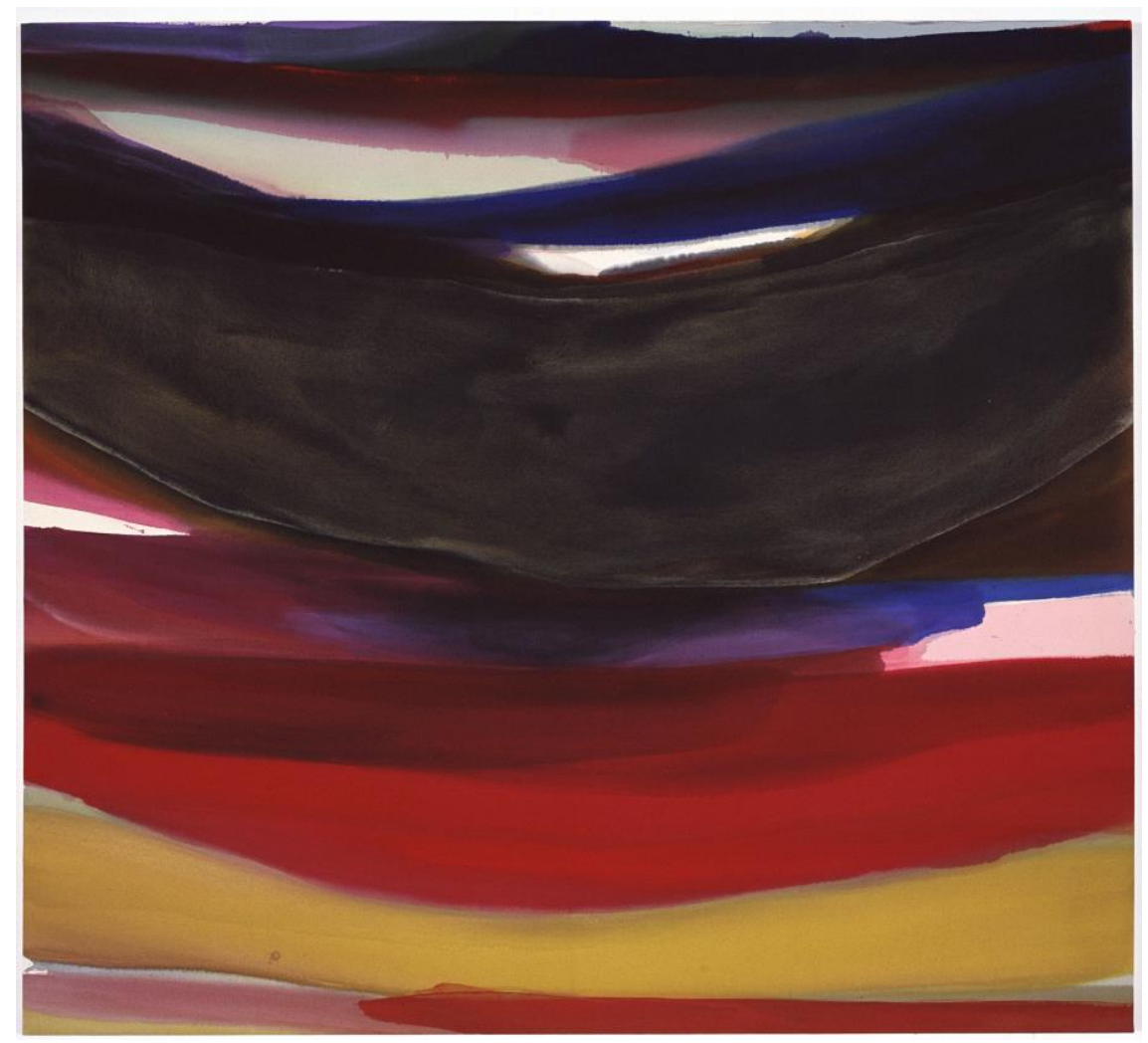

Figure 3. Gretchen Albrecht, Cloud Over Whatipu, 1976. Acrylic on canvas, $1525 \times 1680 \mathrm{~mm}$. Private collection (courtesy of the artist).

So too did Gretchen Albrecht, whose Stained Canvasses (1972-77) have important affinities with McCahon's geometricized landscapes. As McCahon had, in his Titirangi paintings of the 1950s and his later works inspired by Muriwai and Kaipara Flats, Albrecht developed the Stained Canvasses in response to Auckland's West Coast hills and beaches. Piha, Karekare and Whatipu were her favoured destinations to visit [fig. 3]. She reduced her observations of the vistas and conditions she encountered there to a loosely-layered series of colour bands, each the product of a wash of dilute pigment. So heavily abstracted are her finished compositions that were it not for their descriptive titles, they could be seen as nonobjective. As with McCahon, however, her titles invite viewers to regard them as diffusely naturalistic.

Albrecht responded first and foremost in her paintings to American post-painterly abstraction, the watercolour studies of J. M. W. Turner, and the seascapes of Emil Nolde; but McCahon may also be considered a more proximate if also less explicit point of reference. ${ }^{24}$ By the time she began the Stained Canvasses, she had admired his work for at least a decade, and McCahon in turn had been supportive of her practice. He had arranged her first solo exhibition in 1964, she had visited a number of his own shows, and in 1969 she had purchased a painting from him as a gift for her husband James Ross. ${ }^{25}$ She didn't consciously respond to his work, but had 
studied it intently enough that something of his vision of the landscape may well have filtered through to her own.

This "something" was not McCahon's imagery or his spiritual concerns, but rather the approach that he adopted to evoking nature's underlying order. As McCahon had since the late 1930s, Albrecht distilled the landscape to its fundamental attributes. But rather than denude nature entirely by reducing it to bare swathes of geometry, she established a tension within her paintings between the dynamic and organic interactions of her colour bands, which evoked nature's fundamental energies, and the sense that a more perfect striated structure underlay this surface irregularity. It is through this reduction of nature to a schematised ensemble of colour forms that her own impure form of abstraction found its most significant affinity with McCahon's. Just as he hoped his abstraction of the landscape would grant viewers with no knowledge of the sites to which his paintings were connected access to his work's essential meanings, so too did Albrecht use abstraction with a similar intent. By decoupling her response to nature's energies from particular locales, she made the focal features of her experience available to others through a semi-autonomous play of shape and colour. One such feature was the sense of self-dissolving communion with something larger, more powerful and abiding than oneself that views across an open vista can elicit. This experience of ceasing to be oneself and, for a time, becoming no one in particular is Albrecht's version of transcendence. It is also the crux of her abstract universalism, which gives others the chance to share in her responses to nature, whoever and wherever they may be, in accordance with their own sensibilities. 


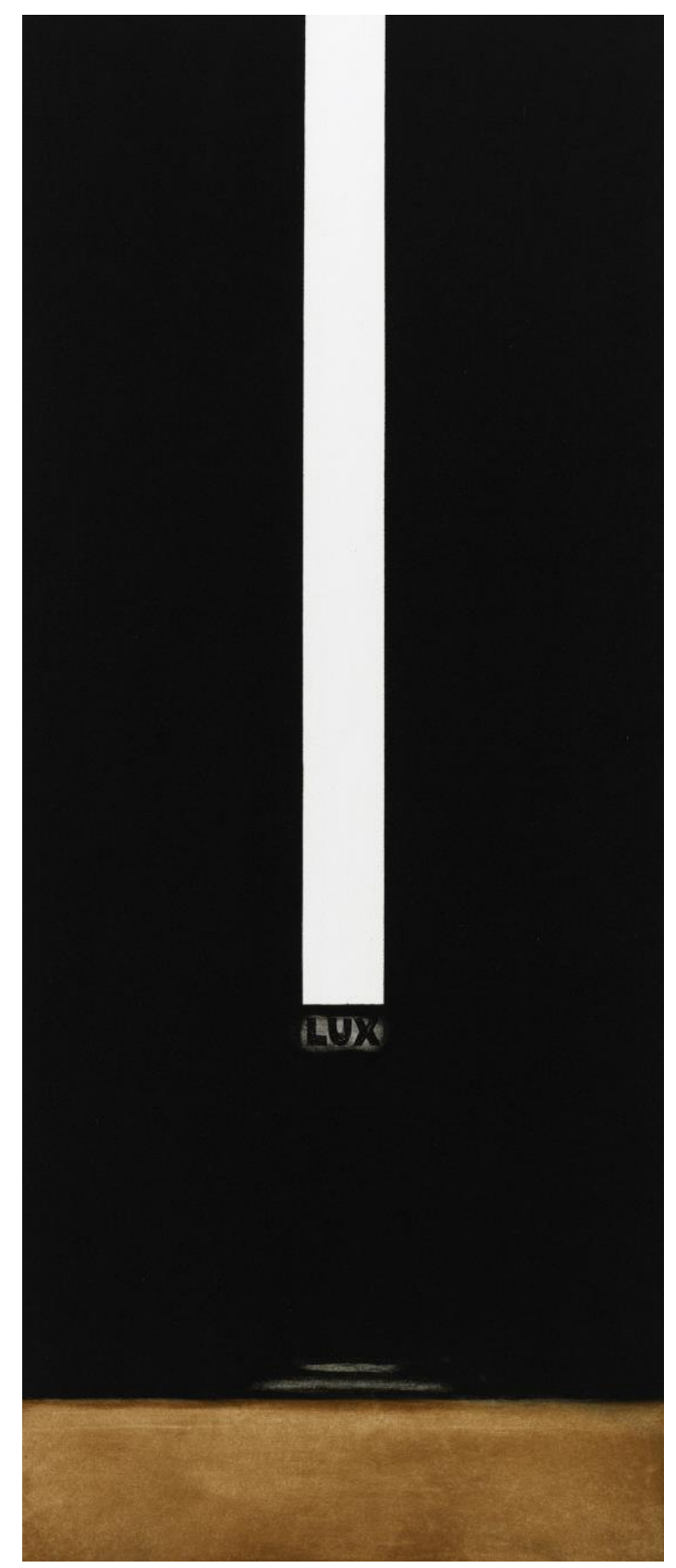

Figure 4. Brent Harris, Lux 1, 1988. Oil on linen, $1880 \times 840 \mathrm{~mm}$. Private collection (courtesy of the artist and Robert Heald Gallery, Wellington).

Throughout the 1970s, Albrecht, McCahon and Hotere were outliers among New Zealand abstract artists, who were otherwise committed to abstraction on pure terms. By the late 1980s, however, this approach had ceased to be as prevalent, a shift evident in the work of Melbournebased Brent Harris, for whom McCahon emerged as a crucial interlocutor at this time. In compositions reduced to black and white geometry and handwritten text from 1988, Harris at once paid homage to and sought to understand McCahon's painting. ${ }^{26}$ Central to this process, and evident in a painting like Lux 1 (1988) [fig. 4], was an engagement with the impurity of McCahon's abstraction - in this case with the landscape intimations of his work of the 1960s and 1970s. Harris valued this device as a way of making abstract compositions more readable, and while he soon moved in a less naturalistic direction, he maintained McCahon's 
commitment to legibility in his next series of paintings, The Stations (1989) [fig. 5], derived from the Stations of the Cross. ${ }^{27}$

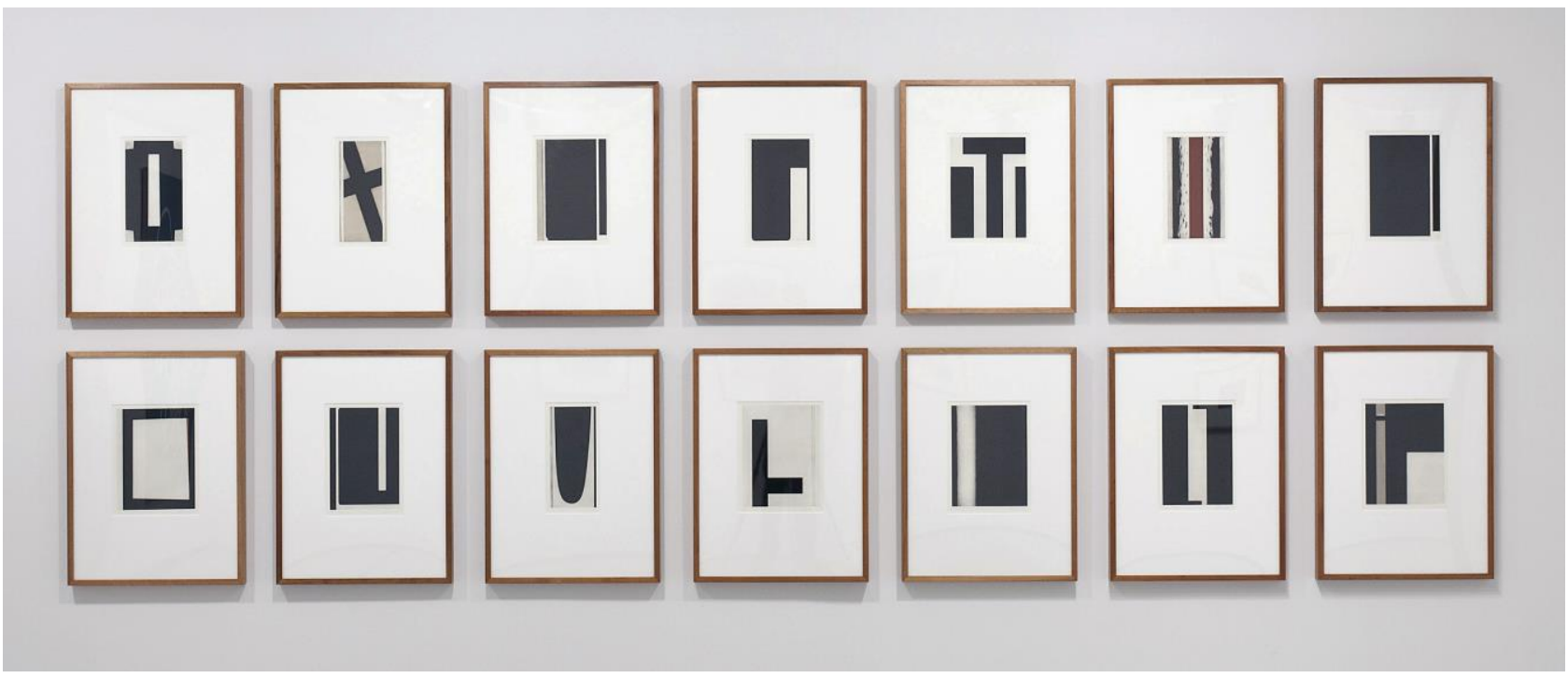

Figure 5. Brent Harris, The Stations, 1989 [print version]. Portfolio of 14 prints: etching, aquatint, roulette, plate-toned, dimensions variable (courtesy of the artist and Robert Heald Gallery,

Wellington).

Like McCahon and Barnett Newman before him, Harris used abstraction to distil the core emotional dynamics of Christ's journey to Golgotha. His paintings bear the conventional Christian titles of the fourteen Stations (Christ before Pilate, He takes the Cross, and so forth), but their imagery recalls that of Newman, McCahon and several other abstract painters. ${ }^{28}$ Each is sparsely geometric and chromatically reduced, its prevailing black and white tonality punctuated by accented areas of red and brown. This reduction makes the series amenable to formalistic readings, as well as readings linking them to spiritual traditions in abstraction. Both were brought to bear when it debuted, but it was also approached on naturalistic terms by some viewers, who responded to its titles. ${ }^{29}$ Christ before Pilate, one critic wrote, "gives a sense of the confrontation of Christ and Pilate by setting up a white form (Christ?) seen through a black shape that hovers in the foreground almost like the back of a figure." ${ }^{30} \mathrm{He}$ Lifts the Cross suggests a hoisted cross. The other paintings echo biblical events in a similar fashion. Several lines of response to the cycle were therefore mooted at the outset, with the more literal Christian layer of meaning providing an initial point of access for some viewers.

Harris has since contributed a fourth way of approaching the Stations, which he preferred not to disclose in the late eighties. ${ }^{31}$ For much of the decade he had been haunted by the AIDS crisis, which had fallen with particular force on the gay community to which he belonged. While working on his paintings, he began to imagine their protagonist as an HIV-positive man and to code his compositions accordingly. At the first station, Christ Before Pilate, the man is judged and condemned to death by society. He bears the burden of his condition throughout the remainder of the series, receiving support from others at key moments (first Simon and then Veronica at stations 6 and 7 respectively), and falling several times as his health deteriorates (stations 3, 7 and 9, signalled near the right edge of each image with a plunging vertical motif). ${ }^{32}$ Within the ambit of this reading, the red accents of stations 7 and 9 (the latter hard to discern from a distance) acquire a charged significance. Socially and virally loaded, they recall 
a decade in which blood became a menace, at once a threat, a source of heartbreak, and a ground for public censure.

Harris had (and still has) no wish to be seen as a gay artist, lest this positioning narrow readings of his work. ${ }^{33}$ In recent years, however, he has grown more open to disclosing the personal dimension of the Stations, which may offer a further point of access for some viewers. There is no question, however, of the cycle being solely about AIDS. ${ }^{34}$ Harris uses the stations as McCahon did: as a mould into which meanings may be poured, each distinctive but converging at an abstract level on shared emotional responses. ${ }^{35}$ In this same spirit, he has recently revisited the subject, using the figurative idiom he has developed since the 1990s. In his new series of Stations, he has been grappling with a different form of suffering: the physical decline of old age, which he now sees ahead of him. ${ }^{36}$

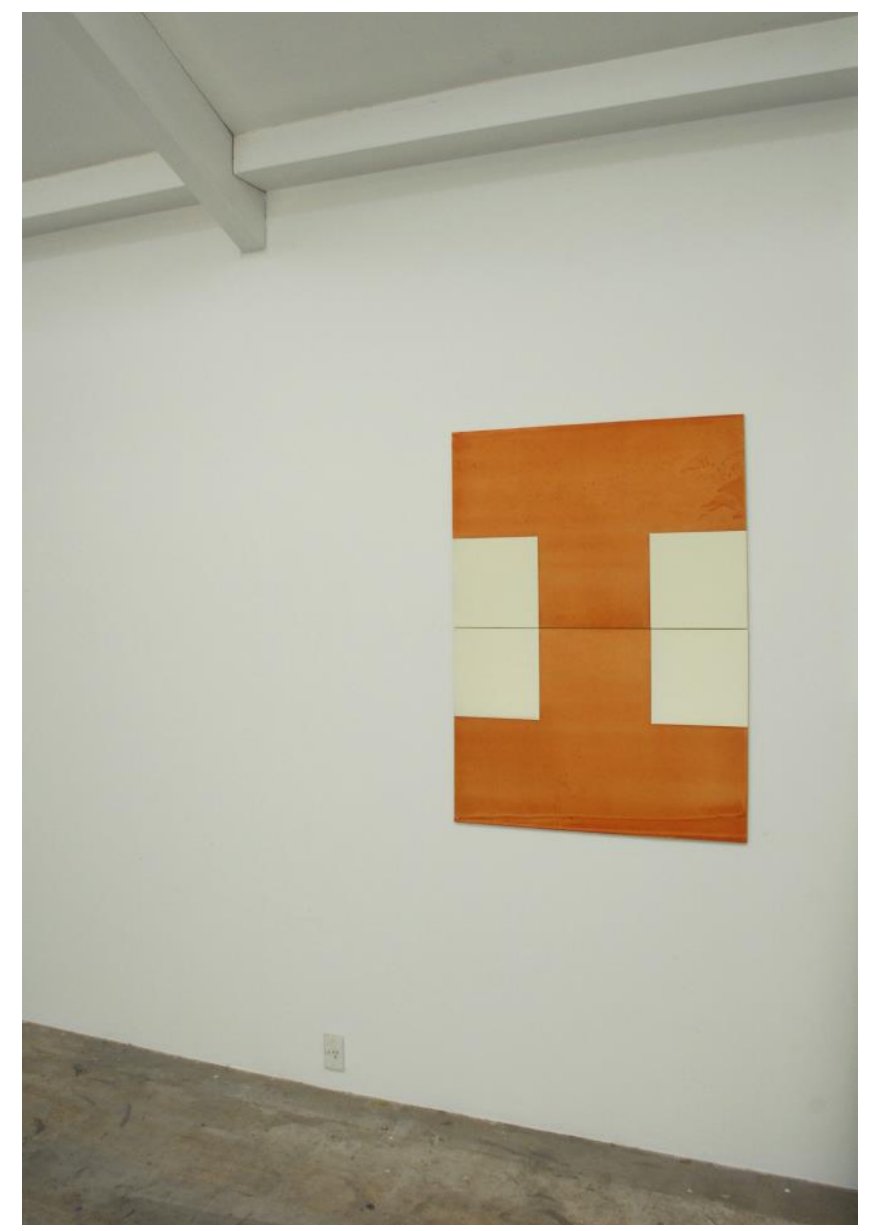

Figure 6. Stephen Bambury, Necessary Correction, 2004-5. Resin and graphite on two aluminium panels, Private collection, Auckland, 1168 x 853 x 7 mm (courtesy of the artist).

Harris has never disavowed his work's connections to McCahon and nor has Stephen Bambury, who has engaged with McCahon at many points in his career, perhaps most prominently in his Necessary Corrections, which he began in the mid-1990s [fig. 6]. In the early 1990s, he had noticed an affinity between the cross motif he was working with and the side-lying " $\mathrm{H}$ " or upright "I" form in McCahon's Necessary Protection (1971) series. ${ }^{37}$ In these and related works, McCahon refigured the offshore island and foreshore cliff face at Muriwai as two 
symmetrical black squares or rectangles, encroaching from either side of the canvas. With these forms in place, the illuminated letter form that occupies the rest of the image became a distillation of a divine beyond, to which the island and cliff forms at once restricted and granted access. Bambury observed that a version of the same form could be created by splitting his cross in two and switching the position of the halves. In his Ladder paintings and Reflected Crosses, in which a series of crosses are linked together, either vertically [fig. 7] or laterally, it was already a latent presence. Bambury's motif has shorter arms than McCahon's, however, and has been stripped of its connection to the landscape. ${ }^{38}$

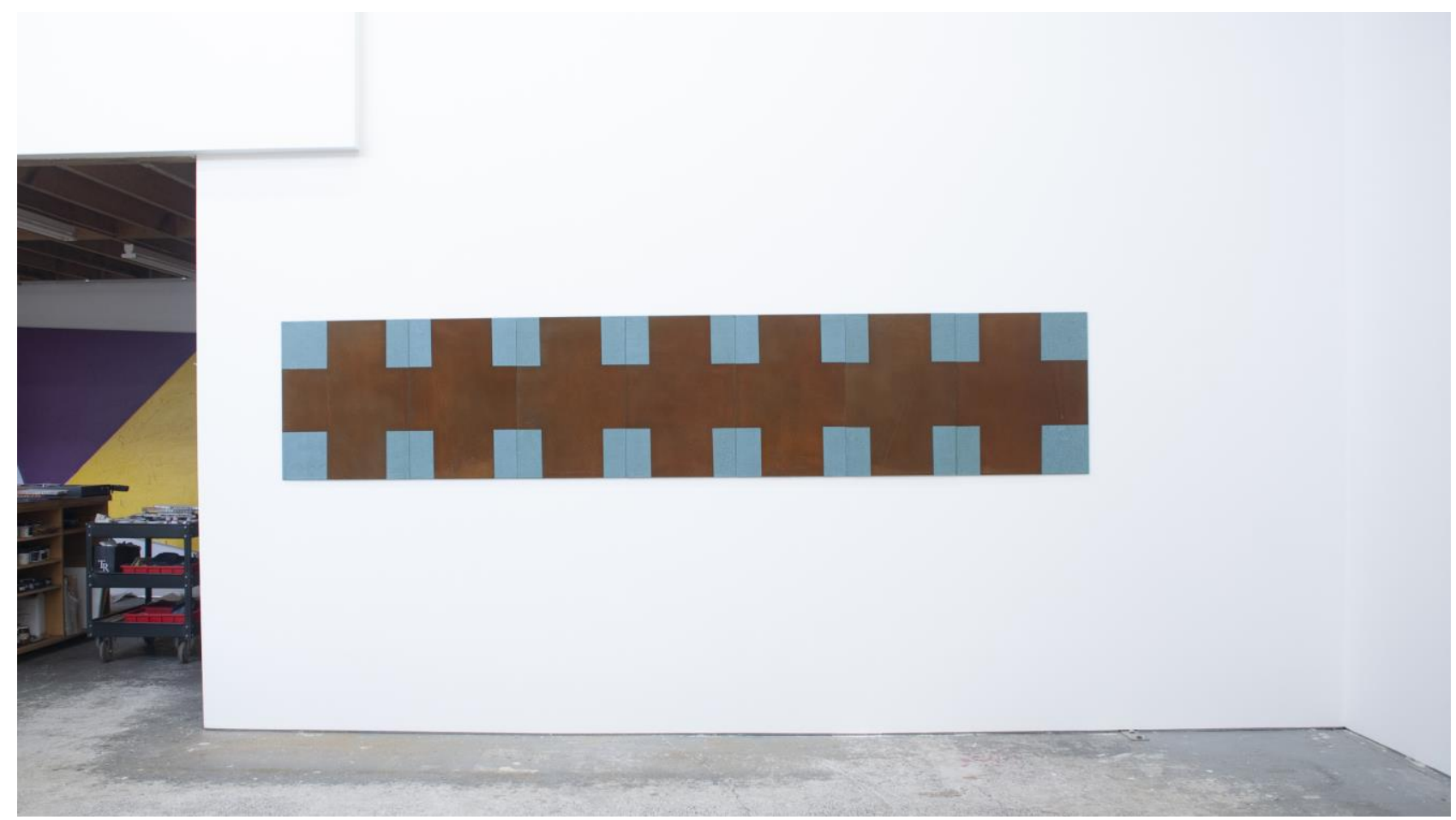

Figure 7. Stephen Bambury, After the Rain, 2019. Iron filings and acrylic on seven aluminium panels, $700 \times 3534$ x $7 \mathrm{~mm}$. Private collection, Australia (courtesy of the artist).

Like McCahon's motif, Bambury's is visually ambiguous. It is legible as an abstract figure resembling letters, but may also be perceived as either positive or negative, which is to say as figure or as ground. As Wystan Curnow, William McAloon and others have noted, this ambiguity, coupled with the physical features of Bambury's paintings, begets a comparable degree of semantic ambiguity and allusiveness. ${ }^{39}$ The resins, oils, metals and other substances with which he has worked over the years inflect the significance of the Necessary Correction motif in different ways, grounding or spiritualising it, purifying or tainting it entropically, and linking it to other points of reference that viewers may pick up on and find resonant. Of special relevance in grasping how the universal functions in Bambury's impurely abstract work is the way in which his "I" form becomes part of a collective in the Reflected Cross and Ladder paintings. In addition to linking many I's together as any collective must, two of the latter works are titled Advaita, a Sanskrit word that, as Curnow has observed, refers to "the nonduality of the Universal spirit with the individual soul." ${ }^{40}$ In the spirit of Bambury's willingness to open the forms within his paintings to their cognates and affiliates in other contexts, we might also observe that when a chain of "I's" or "H's" is lain sideways, it resembles a primal evocation of collective strength and unity: a row of repeated human figures, like those which 
appear in an early Arowhenua rock drawing (with possible alterations by Theo Schoon), for example. Such cross-cultural and transhistorical connections, made manifest through Bambury's embrace of impure abstraction, form the connective tissue of his universalism.

Imogen Taylor's recent engagement with McCahon has centred on his work of the 1950s. As is by now inevitable for abstract artists, Taylor works with familiar forms and imagery, especially those relating to Cubism and geometric abstraction. ${ }^{41}$ In much of her work, she has been concerned to foreground female pleasure and has often made allusions to lesbian sexuality. ${ }^{42}$ Her work has thus been understood as "queering" both the imagery and expressive aspirations of male modernists. ${ }^{43}$ Sensualising forms that were historically linked to more cerebral and spiritual practices has been one of her approaches to this process. ${ }^{44}$ Imbuing imagery conceived in earnest with a more playful sensibility is another. ${ }^{45}$

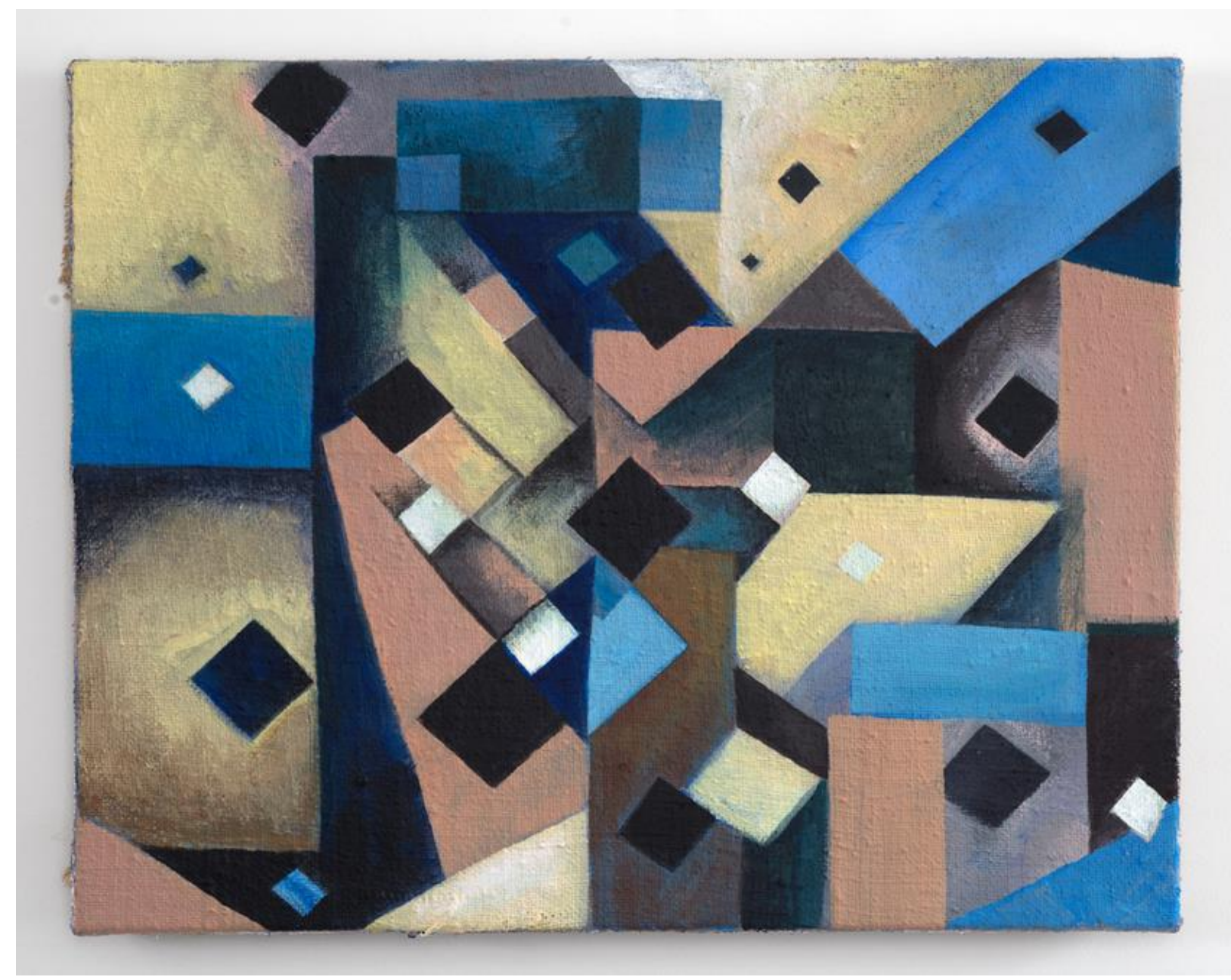

Figure 8. Imogen Taylor, Full Moon/King Tide, 2016. Acrylic on hessian, $600 \times 500 \mathrm{~mm}$. Private collection (courtesy of the artist and Michael Lett Gallery, Auckland).

Taylor's Full Moon/King Tide (2016) [fig. 8] feels less humorous and eroticised than many of her paintings, but is typical in its somatic emphasis. It is this latter quality that sets it apart from the McCahon works that informed it. ${ }^{46}$ Taylor's painting recalls the French Bay landscapes of the 1950s [fig. 9], in which views of the coastline and ocean dissolve into swarms of animated rectangles. ${ }^{47}$ But its manner of addressing the viewer is less insistently optical than McCahon's 
by virtue of its spatial construction. The French Bay paintings appear resolutely flat, a quality deriving from the dense scattering of shapes across their surfaces. In many cases, there are hints of landscape lying beyond this veil of surface patterning. Both registers of imagery appeal chiefly to the eye, however, and do not implicate the body: the surface shapes have a prismatic quality and threaten to dissolve the visual field into a seething sea of optical pulsations; the underlying landscape is so remotely located and fragmented as to feel both unreachable and intangible. Taylor's work offers occasional intimations of deep space, especially in its pale yellow moonlit regions. For the most part, however, it consists of a cubist niche space that pulls in multiple and conflicting directions. The sparsely distributed hanging diamond forms she has scattered across her painting's foreground nod to McCahon's jostling rectangles, but are steadier and more cleanly delineated. They are optically reverberant like McCahon's shapes, but do not hinder access to the space behind them. We are thus able to project ourselves somatically into the work's background recesses in a way that is impossible with McCahon. Together, the two registers of imagery make for a dynamic composition that tugs and prods the viewer bodily in myriad directions. McCahon's paintings, by contrast, hold the body and the gaze at a distance.

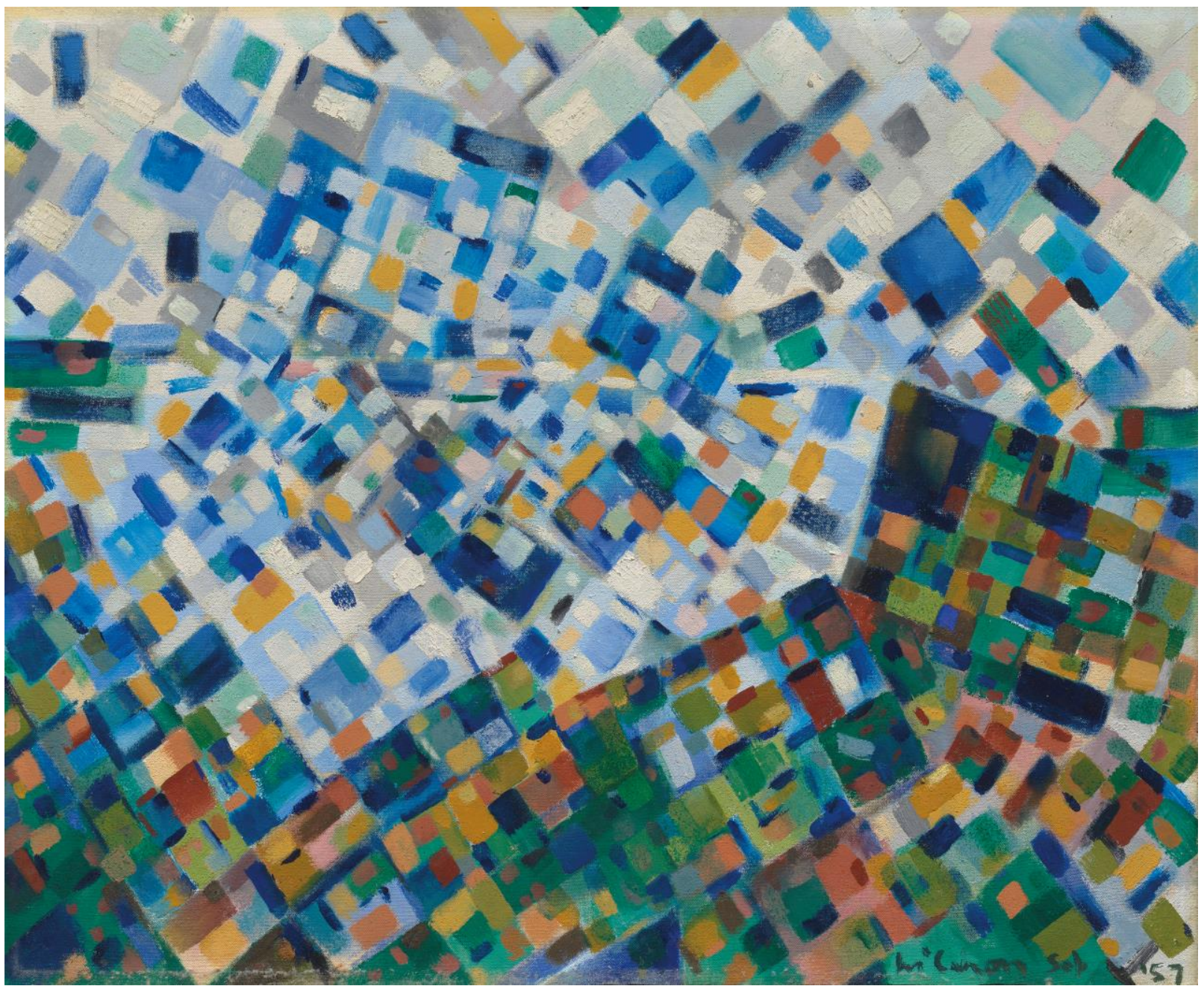

Figure 9. Colin McCahon, French Bay, 1957. Oil on hardboard, $430 \times 570 \mathrm{~mm}$. Private collection (courtesy of the Colin McCahon Research and Publication Trust). 
Taylor may address the viewer on different terms than McCahon, but she uses abstraction to bridge difference in the same way that he did. The imagery in her painting may have issued from her own embodied standpoint, but viewers need not be either queer or female to respond to it. Its spatial and somatic dynamics are available to anyone, regardless of the bodies they inhabit and their social positioning. Each viewer will experience her painting differently, but these inflections will share a common core.

Like many contemporary artists, Taylor is working to increase opportunities for artists from historically marginalised social groups. In addition to her publishing efforts on behalf of women in the art world, she recently curated an exhibition that put her work in dialogue with paintings by several female New Zealand modernists of the early and mid-twentieth century. ${ }^{48}$ Common concerns of the works exhibited were female pleasure, desire and close companionship - intimate and possibly erotic. By connecting her own work to a lineage of similar practices, Taylor has added a new narrative thread to local art history. There is currently a good deal of revisionist historicising occurring in this vein, both locally and internationally. Its goal is to eliminate the white male bias that persists in most areas of the discipline. Work like this is welcome and necessary, but Taylor's and other abstract artists' engagements with McCahon suggest an alternative approach to making art history more inclusive. Instead of focussing on the sectional and intersectional identity categories that are the primary areas of interest in the art world, the narrative outlined in this article traverses the categories of gender, ethnicity and sexuality on which identity-driven politics tends to focus. Without denying the pertinence of these categories, it points to impure abstract painting's capacity to cut across and unite them. 


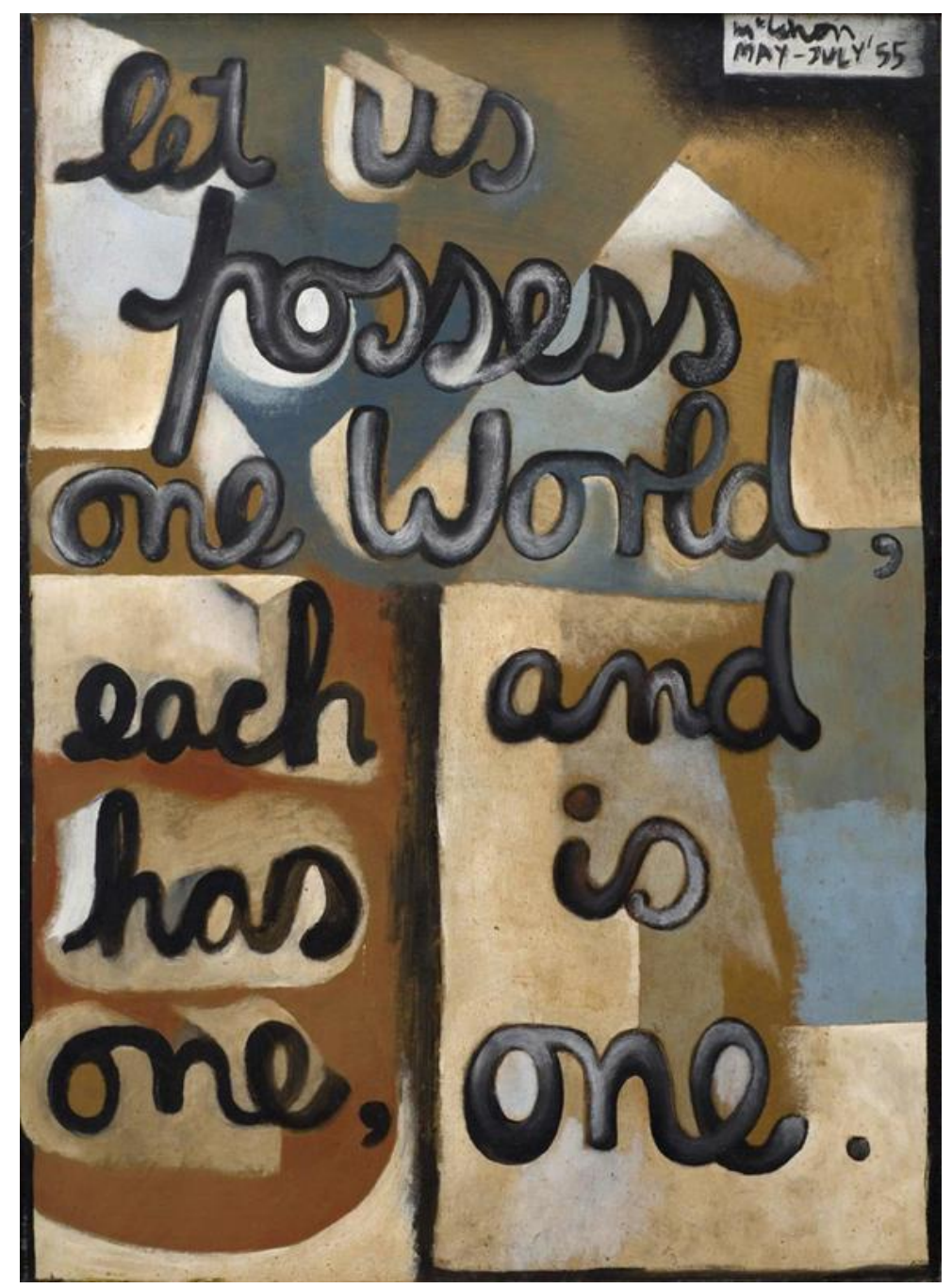

Figure 10. Colin McCahon, Let us possess one world, 1955. Oil and enamel on board, $750 \times 550 \mathrm{~mm}$. University of Auckland (courtesy of the Colin McCahon Research and Publication Trust).

Keeping identity and difference in play in this transversal fashion requires an approach toartmaking in which abstraction and representation collaborate. The generalising power of the former works to open up art's semantic horizons. The latter affirms difference and offers points of access to a work for some viewers. Each of the artists who have drawn on McCahon's abstract work has struck this balance distinctively. In so doing, they have responded to a call made in one of his first written paintings: "[L]et us possess one world, each has one, and is one" reads its inscription [fig. 10]. With these words, borrowed from John Donne and John Caselberg, McCahon affirmed one of his chief aims as an artist: to forge a promised land of experience in which unity and difference could coexist, their respective strengths and weaknesses holding one another in balance, the freedoms of the individual acknowledged and upheld, the strength and support of the collective mitigating the conflict and isolation to which these freedoms give rise. ${ }^{49}$ Beneath this inscription lies a variegated patchwork of colour, in which there are few secure boundaries between adjacent shapes and hues. There is, however, one clear threshold present, which divides the lower half of the canvas in two, a division its upper regions lack. Without McCahon's inscription this wavering black column might be read in a variety of ways or merely taken as an abstract caesura. With text in place, however, it suggests that the divisions in experience that make each of us a world in and for ourselves need not be absolute. They thus should not prevent us from gaining access to a realm of shared 
experience that, as his painting indicates, is more elevated. McCahon fell short of his utopian ambition to foster this transcendence universally with his art, but in the more restricted context of those who value his work today, he has succeeded. His impure approach to abstraction has been in large part responsible for this achievement.

My thanks to Gretchen Albrecht, Stephen Bambury, Brent Harris, and Imogen Taylor for discussing their engagement with McCahon with me.

${ }^{1}$ On the criticisms occasioned by McCahon's engagements with Māori culture and subject matter, see Ngahuia Te Awekotuku, "Ngahuia Te Awekotuku in Conversation with Elizabeth Eastmond and Priscilla Pitts," Antic no. 1 (1986): 44-55; Jonathan Mane-Wheoki, "An Ornament for the Pakeha: Colin McCahon's Parihaka Triptych," in Parihaka: The Art of Passive Resistance, ed. Te Miringi Hohaia, Gregory O'Brien and Lara Strongman (Wellington: Victoria University Press, 2001), 129-38; Robert Leonard and Wystan Curnow, Colin McCahon: On Going Out with the Tide (Wellington: City Gallery Wellington, 2017), n.p.; and Matariki Williams, "Tūhoe Country: Colin McCahon and his Te Urewera Paintings," Te Papa Tongarewa, https://blog.tepapa.govt.nz/2020/03/04/tuhoe-country-colinmccahon-and-his-te-urewera-paintings/.

${ }^{2}$ Linda Tyler, "I Did Not Want to be Mrs Colin: Anne \& Colin McCahon," in Between the Lines: Partners in Art, ed. Deborah Shepard (Auckland: Auckland University Press, 2013), 31-53; and Linda Tyler, A Table of One's Own: The Creative Life of Anne McCahon (Auckland: McCahon House Trust, 2016).

${ }^{3}$ On the conflicting estimations of the effects of McCahon's behaviour while drinking, see Martin Edmond, "A Family Plot," in this volume. For recollections by McCahon's son William about his father's abusive behaviour, see Linda Herrick, "Looking Back in Anger: Colin McCahon's Family Portrait," New Zealand Herald, 29 August 2002,

http://www.nzherald.co/lifestyle/news/article.cfm?c_id=6\&objected=2351929.

${ }^{4}$ This reservation is typically expressed off the record. For notable exceptions, see Shannon Te Ao, "The Problematic Legacy of Colin McCahon," The Spinoff, 21 September 2019, https://thespinoff.co.nz/art/21-09-2019/the-problematic-legacy-of-colin-mccahon/, and the contributions of Leonard Bell, Anna Parlane and Matariki Williams to this volume.

${ }^{5}$ Shannon Te Ao has connected the unstinting promotion of McCahon as New Zealand's greatest artist to "The maintenance of a dominant, male Pākehā narrative" in local art history (Te Ao, "Problematic Legacy"). Christina Barton's catalogue essay for her 1989 exhibition, After McCahon: Some Configurations in Recent Art, also linked McCahon's cultural standing to a bias in favour of white male artists, albeit less directly. Discussing the McCahon-related work of Emare [Emily] Karaka and other female artists in the exhibition, Barton observed: "Clearly then, that [i.e. McCahon's] prophetic voice no longer resounds over the land, leaving room for a groundswell of 'other' voices" (Christina Barton, "After-words: Conversation around McCahon," in After McCahon: Some Configurations in Recent Art [Auckland: Auckland Art Gallery, 1989], 12.)

${ }^{6}$ Zoe Alderton's The Spirit of Colin McCahon (Newcastle, UK: Cambridge Scholars Publishing, 2015 ) is the exception that proves the rule of Pākehā male authorship of McCahon monographs. For the McCahon House Trust essays, see https://mccahonhouse.org.nz/100.

${ }^{7}$ On the role of the "Promised Land" as an ideal and guiding principal in McCahon's art, see Gordon H. Brown, "Colin McCahon and the Promised Land", in Gordon H. Brown, Towards A Promised Land: On the Life and Art of Colin McCahon (Auckland: Auckland University Press, 2010), 123-36.

${ }^{8}$ Two of many related comments by McCahon make evident his wish to convey messages of universal relevance to a universal audience. At the outset of his career, in the late 1930s, he wrote to Toss Woollaston of his hopes for the reception of his early landscape painting Harbour Cone with Peggy's Hill (1939), which had just been rejected for exhibition by the Otago Art Society: "I imagined people looking at it then looking at a landscape $\&$ for once really seeing it $\&$ being happier for it $\&$ then believing in God $\&$ the brotherhood of men $\&$ the futility of war $\&$ the impossibility of 
people owning \& having more right to a piece of air than anyone else. . . Communism it is said stamps out Christianity. Christianity as practised it does stamp out but true communism means true Christianity \& I believe that by my painting I help to bring it about" (McCahon, letter to Toss Woollaston, 8 December 1939, cited in Peter Simpson, Colin McCahon: There Is Only One Direction. Vol. 1 1919-1959 [Auckland: Auckland University Press, 2019], 50.) A decade later, in a letter to his parents, McCahon chastised the poet Allen Curnow, a committed cultural nationalist, for "too consciously pushing local against universal" in his advocacy on behalf of New Zealand authors (McCahon, letter to his parents, 30 December 1947, cited in Simpson, There Is Only One Direction, 97.) Decades of rejection and misreading of his work would dim McCahon's hopes for achieving anything of this kind, but he continued to address his art to "man," to "the human condition," and to "us" in an unqualified and unrestricted sense.

${ }^{9}$ In a frequently cited reference to the work of Piet Mondrian and his own desire to find a way to move beyond it, McCahon concluded that the "only way is not more 'masking-tape' [like that used by Mondrian in his paintings] but more involvement in the human situation" (McCahon in Colin McCahon: A Survey Exhibition [Auckland: Auckland City Art Gallery, 1972], 28.) By this he likely meant that pure abstract painting, in the vein of Mondrian's, bore too little resemblance to reality to be of use to viewers, like himself, in their efforts to contend with worldly problems. He felt that keeping his own work connected to the real world via hints of naturalism, signs and symbols would give it this utility.

${ }^{10}$ This reception is outlined in Marja Bloem and Martin Browne, "Chronology," in Colin McCahon: A Question of Faith, ed. Marja Bloem and Martin Browne, (Nelson: Craig Potton

Publishing/Amsterdam: Stedelijk Museum, 2002), 193. It is explored in greater depth in Peter Simpson, Colin McCahon: Is This the Promised Land? Vol. 2 1960-1987 (Auckland: Auckland University Press, 2020), 20-21.

${ }^{11}$ McCahon did not produce his first work referring explicitly to the stations until 1966 (The Fourteen Stations of the Cross [1966]), but in view of its shared thematics and appearance a year prior to that work, Numerals can plausibly be linked to it.

${ }^{12}$ Constraints of space mean that this selection of artists is only partial. Other New Zealand abstract painters who have engaged with McCahon's work include Julian Dashper, Judy Millar, John Reynolds and James Ross.

${ }^{13}$ On McCahon's interest in the work of these painters and in nonobjective painting more generally, see: Wystan Curnow, "Thinking about Colin McCahon and Barnett Newman" (1977), reprinted in abridged form in Wystan Curnow, The Critic's Part: Wystan Curnow Art Writings, 1971-2013 (Brisbane: Institute of Modern Art/Wellington: Adam Art Gallery/Wellington: Victoria University Press, 2014), 83-88; Tony Green, "McCahon and the Modern," in Colin McCahon: Gates and Journeys (Auckland: Auckland City Art Gallery, 1989), 32-35; and Simpson, Is This the Promised Land, 11-14, 22-32.

${ }^{14}$ On Richter and Viking Eggeling's designation of geometric abstraction as a Universelle Sprache [universal language], see Hans Richter and Viking Eggeling, "Demonstration of the "Universal Language"' (1920), reprinted in Hans Richter: Activism, Modernism and the Avant-Garde, ed. Stephen C. Foster (Cambridge, MA: MIT Press, 1998), 184-239. The related notion of abstract as a worldwide language of postwar art is discussed in Werner Haftmann, "Malerei nach 1945," in II. documenta 59 (Kassel: Museum Fredericianum, 1959), 14-16. On the transcendental impulse in early and mid-twentiewth-century abstraction, see John Golding, Paths to the Absolute: Mondrian, Malevich, Kandinsky, Pollock, Newman, Rothko and Still (London: Thames \& Hudson, 2002).

${ }^{15}$ Simpson, Is This the Promised Land, 20.

${ }^{16}$ Simpson, Is This the Promised Land, 34, 36.

${ }^{17}$ Locally, Milan Mrkusich and Gordon Walters remained firmly committed to purity in their work and would influence many younger abstract painters in Auckland in the 1960s and 1970s. (On this relationship, see Ed Hanfling and Alan Wright, Vuletic and his Circle [Auckland: Gus Fisher Gallery, 2003]). Internationally, the lofty spiritual and transcendental approaches to abstraction to which McCahon was drawn fell away in the 1960s. They were supplanted, however, by formalist and 
minimalist approaches that were equally preoccupied with purity and remained dominant until the late 1970s. (On the waning of the pure, formalist approach to abstraction in New Zealand in the 1980s, see Luke Smythe, Gretchen Albrecht: Between Gesture and Geometry [Auckland: Massey University Press, 2019], 113.)

${ }^{18}$ Ralph Hotere, Zero (Auckland: Barry Lett Galleries, 1967), n.p.

${ }^{19}$ Hotere, Zero.

${ }^{20}$ See, for example: David Eggleton, "From Absence to Presence," in Ralph Hotere Black Light: Major Works, Including Collaborations with Bill Culbert, ed. Gregory O'Brien and Ralph Hotere (Wellington: Te Papa Press; Dunedin: Dunedin Public Art Gallery, 2000), 61-69; Vincent O’Sullivan, "Sketching the Artist," in Ralph Hotere, Kriselle Baker and Vincent O'Sullivan, Ralph Hotere (Auckland: Ron Sang Publications, 2008), 306-19; and Gregory O’Brien, "Rain in Northland: Colin McCahon, Ralph Hotere and the Painted Word," Journal of New Zealand Literature 36, no. 2 (July 2018): 57-69.

${ }^{21}$ Kriselle Baker, "He Kuaka Marangaranga: A Godwit that Hovers," in Hotere, Baker and Sullivan, Ralph Hotere, 125-26; and Sullivan, "Sketching the Artist," 314.

${ }^{22}$ Hotere's use of language has been discussed most extensively and attentively by Gregory O'Brien (See, Gregory O'Brien, "Miserere Mitimiti: A Meeting-Place," Poetry Nation Review 25, no. 4, (March/April 1999): 26-32; and Gregory O'Brien, Hotere: Out the Black Window: Ralph Hotere's Work with New Zealand Poets [Auckland: Godwit/Wellington: City Art Gallery, 1997]).

${ }^{23}$ On Hotere's engagements with Manhire, see, for example: O’Brien, "Miserere Mitimiti," 28; and O'Sullivan, "Sketching the Artist," 314.

${ }^{24}$ On Albrecht's responses to these artists, see Smythe, Between Gesture and Geometry, 42-56, 61, 259 , and 291.

${ }^{25}$ McCahon was the instigator of Albrecht's first one-person exhibition, at Auckland's Ikon Gallery. The work Albrecht purchased for Ross was I and Thou (1969), the first of sixteen McCahons the couple would acquire over the years. (Albrecht, email to author, 25 July 2020.) Albrecht has discussed her response to another of these works, As There Is a Constant Flow of Light We Are Born into the Pure Land (1965), in a recent essay: https://mccahonhouse.org.nz/100/gretchen-albrecht. ${ }^{26}$ As Harris remarked to Ashley Crawford at the time (Ashley Crawford, "Brent Harris: Between Quotation and Homage," Tension 15 (1988): 20.

${ }^{27}$ Describing Lux in 1989, Harris observed: "The Lux painting is connected to the way McCahon would use the landscape-it gives the painting a readable space, like giving it handles" (Brent Harris, cited in Crawford, "Between Quotation and Homage," 21).

${ }^{28}$ On McCahon and Newman's respective engagements with the Stations of the Cross, see Curnow, "Thinking about McCahon and Barnett Newman," 83-87; and Michael Dunn, "McCahon's Survey Exhibition," Arts \& Community 8, no. 4 (April 1972): 2-3. In addition to McCahon and Newman, Harris responded the work of Elsworth Kelly and Ad Reinhardt.

${ }^{29}$ Formalistic and abstract spiritual readings of the Stations were offered by Harris himself and Ashley Crawford (see Crawford, "Between Quotation and Homage," 20-23). A diffusely naturalistic interpretation was offered by Alan Dodge ("Brent Harris: The Stations," Tension 18 [1989]: 8-9).

${ }^{30}$ Dodge, "Brent Harris," 8.

${ }^{31}$ Brent Harris, conversation with the author, 18 August 2020. Only in the past year have the Stations been linked publicly to the AIDS crisis, by Lara Strongman (see Lara Strongman, "Appalling Moments and Abstract Elegies," in Bulletin 198 [Christchurch: Christchurch Art Gallery Te Puna Waiwhetu, 2019]: 11).

${ }^{32}$ Brent Harris, conversations with the author, 20 July and 18 August 2020.

${ }^{33}$ Harris, conversation with the author, 18 August 2020.

${ }^{34}$ Harris, conversation with the author, 18 August 2020.

${ }^{35}$ On McCahon's use of the Stations of the Cross as "a kind of armature or 'grid' to hang things on," see Peter Simpson's contribution to this volume.

${ }^{36}$ Harris, conversation with the author, 8 August 2020.

${ }^{37}$ Stephen Bambury, email to the author, 25 August 2020. 
${ }^{38}$ The shorter arms and stouter proportions of Bambury's motif are due to his derivation of its proportions from the black cross of Kazimir Malevich. (Bambury, email to the author, 25 August 2020).

${ }^{39}$ See Wystan Curnow, "Necessary Correction," and William McAloon, "Border Crossings," both in Necessary Correction: Colin McCahon, Stephen Bambury, Helmut Federle (Auckland: Auckland Art Gallery, 1997), n.p. As Robert Leonard has observed, "though [Bambury's] abstract paintings may appear formal, self-referential, exclusively visual (in that arch-modernist vein), they also absorb the world, asking to be read in relation to the diverse things, histories, philosophies, and opportunities around them" (Robert Leonard, "Chakra" [1999], republished at: https://robertleonard.org/stephenbambury-chakra).

${ }^{40}$ Wystan Curnow, "Stephen Bambury" (2000), reprinted in Curnow, The Critic's Part, 359.

${ }^{41}$ On this aspect of Taylor's work, and especially her engagements with Cubism, see Julia Waite, "Imogen Taylor: In the Wake of" (Auckland: Te Uru Contemporary Art Gallery, 2018), n.p.

${ }^{42}$ See, for example, Taylor's comments on the "smuttiness" of her work in Lucinda Bennett, "Two Sides of the Glory Hole," Express (6 October 2014): https://gayexpress.co.nz/2014/10/two-sidesglory-hole. The queer dimension of Taylor's work has been discussed extensively in: Owen Connors, "Give and Take: Imogen Taylor's Glory Hole and Political Camp," Pantograph Punch (30 June 2015): https://pantograph-punch.com/posts/imogen-taylor-glory-hole; and Bridie Lonie, "On Queer Pleasure: Conversations between Imogen Taylor and Frances Hodgkins," The Spinoff, 8 March 2020, https://thespinoff.co.nz/art/08-03-2020/on-queer-pleasure-conversations-between-imogen-taylor-andfrances-hodgkins.

${ }^{43}$ Connors, "Give and Take," n.p.

${ }^{44}$ Lonie, "On Queer Pleasure," n.p.

${ }^{45}$ See the comments on Taylor's ironic recapitulations of the imagery of male abstract artists, in Waite, "In the Wake of," n.p.; and Julie Hill, "You're Equal," Paper Boy, 23 February 2017: 32-37.

${ }^{46}$ Taylor painted Full Moon/King Tide while living at Piha, in the lead-up to her 2017 artist's residency at McCahon House in Titirangi. The work reflects her interest in exploring how the Waitakere landscape may have influenced McCahon's French Bay works (Imogen Taylor, communication to the author, 7 October 2020). For further discussion of Full Moon/King Tide and related works in connection with McCahon, see Waite, "In the Wake of," n.p.; and Hill, "You're Equal," 34-35, 37.

${ }^{47}$ Taylor first became aware of affinities between her own paintings and the French Bay works in 2013, when Melbourne gallerist Vasili Kaliman remarked on them. A period of more conscious engagement with the series followed and culminated in Taylor's 2016 exhibition "In \& Out" at Michael Lett Gallery in Auckland. Her interest in McCahon's work of the fifties reflects her preference for his more lyrical and light-hearted work of this period, as opposed to his later more reductive and sombre output (Taylor, communication to the author, 7 October 2020).

48 "Sapphic Fragments," Hocken Gallery, Dunedin, 1 February-28 March 2020. Taylor and Judy Darragh co-edit and manage Femisphere, a magazine "encouraging inclusivity and visibility" for women in the New Zealand art world: https://femisphere.co.nz/about.

${ }^{49}$ The source of the text in Let Us Possess One World (1955) is John Donne's poem 'The Good Morrow' (1633). As Peter Simpon notes, McCahon had probably come across this line in a poem by his friend John Caselberg (Simpson, There is Only One Direction, 210). 